Jurnal Insan Farmasi Indonesia, 3(2) Desember 2020 (291-297)

Fef Rukminingsih

p-ISSN 2621-3184; e-ISSN 2621-4032

doi: 10.36387/jifi.v3i2.619

\title{
PENGUKURAN TEKANAN DARAH PADA PASIEN PESERTA JKN DENGAN PENYAKIT JANTUNG ISKEMIK DI INSTALASI RAWAT JALAN RUMAH SAKIT ST. ELISABETH SEMARANG
}

\author{
Fef Rukminingsih*, Nike Kusuma Dewi \\ Politeknik Katolik Mangunwijaya Semarang \\ *: fefrukminingsih@gmail.com
}

\begin{abstract}
ABSTRAK
Penyakit Jantung Iskemik (PJI) didefinisikan sebagai kekurangan oksigen dan penurunan atau tidak adanya aliran darah ke miokardium yang disebabkan oleh penyempitan arteri koroner. Hipertensi merupakan faktor risiko yang berperan penting terhadap PJI. Terapi hipertensi pada pasien PJI bertujuan untuk mencegah kematian, infark miokardial, stroke, pengurangan frekuensi dan durasi iskemia miokard dan memperbaiki tanda serta gejala. Penelitian ini bertujuan untuk mengevaluasi ketercapaian target tekanan darah pada pasien PJI peserta JKN di Instalasi Rawat Jalan Rumah Sakit St. Elisabeth Semarang. Penelitian ini merupakan penelitian deskriptif observasional menggunakan data retrospektif. Data diperoleh dari rekam medik. Kriteria inklusi penelitian ini adalah pasien peserta JKN dengan diagnosa PJI di Instalasi Rawat Jalan Rumah Sakit St. Elisabeth Semarang periode Oktober-Desember 2019 yang mendapat terapi antihipertensi, berumur 26-65 tahun, mempunyai data tekanan darah selama dua bulan berurutan. Berdasarkan hasil penelusuran data rekam medis diperoleh data sebanyak 88 pasien, terdiri dari 64 (72,73\%) pasien laki-laki, 46 (52,27\%) pasien berumur 56-65 tahun. Sebanyak 57 pasien $(64,78 \%)$ mempunyai penyakit penyerta dan penyakit penyerta terbanyak adalah DM tipe 2. Agen antihipertensi yang paling banyak digunakan adalah beta blocker. Sebanyak $82(93,18 \%)$ pasien mencapai target tekanan darah berdasarkan JNC 8. Semakin besar keberhasilan mencapai target terapi maka risiko kematian akibat PJI akan menurun.
\end{abstract}

Kata Kunci: Penyakit jantung iskemik, hipertensi, tekanan darah, RS St. Elisabeth.

\section{ABSTRACT}

Ischemic heart disease (IHD) is defined as a lack of oxygen and decreased or absent blood flow to the myocardium caused by narrowing of the coronary arteries. Hypertension is a risk factor that plays an important role in IHD. Hypertension therapy in IHD patients aims to prevent death, myocardial infarction. This study aims to evaluate the achievement of blood pressure targets in IHD patients participating in JKN in the outpatient installation of St. Elisabeth Hospital Semarang. This research is a descriptive observational study using retrospective data. Data obtained from the medical records. The inclusion criteria were JKN participant patients with IHD in the Outpatient Installation of St. Elisabeth Hospital Semarang for the period of October-December 2019 who received antihypertensive, aged 26-65 years, had blood pressure data for two consecutive months. The results were 88 patients, consisting of 64 (72.73\%) male patients, 46 
Jurnal Insan Farmasi Indonesia, 3(2) Desember 2020 (291-297)

Fef Rukminingsih

p-ISSN 2621-3184; e-ISSN 2621-4032

doi: 10.36387/jifi.v3i2.619

(52.27\%) patients aged 56-65 years. 57 (64.78\%) patients had comorbidities, the most comorbidities were type 2 diabetes. The most widely used antihypertensive agents were beta blockers. A total of $82(93.18 \%)$ patients reached the target blood pressure based on JNC 8. The greater the success in achieving the therapeutic target, the risk of death from IHD will decrease.

Keywords: Ischemic heart disease, hypertension, blood pressure, St. Elisabeth Hospital

\section{PENDAHULUAN}

Penyakit jantung dan pembuluh darah merupakan penyebab utama kematian baik di Indonesia maupun di dunia. Insiden kematian mendadak dari gangguan ini sangat tinggi. Prevalensi penyakit jantung di Indonesia sebesar $1,5 \%{ }^{1}$. Penyakit Jantung Iskemik (PJI), disebut juga Penyakit Arteri Koroner (PAK), didefinisikan sebagai kekurangan oksigen dan penurunan atau tidak adanya aliran darah ke miokardium yang disebabkan oleh penyempitan arteri koroner ${ }^{2}$.

Hipertensi merupakan faktor risiko yang berperan penting terhadap PJI. Tekanan darah yang tinggi secara terus menerus akan menyebabkan kerusakan sistem pembuluh darah arteri $^{3}$. Tujuan jangka pendek dari terapi PJI adalah untuk mengurangi atau mencegah gejala angina yang membatasi kemampuan aktivitas fisik dan memperbaiki kualitas hidup.
Tujuan jangka panjang adalah untuk mencegah Penyakit Jantung Koroner (PJK) seperti infark miokardial, aritmia, dan gagal jantung serta untuk meningkatkan kualitas hidup pasien. Tatalaksana terapi farmakologi yang digunakan yaitu golongan $\beta$ Adrenergic Blocker, Nitrat, Calcium Channel Blockers, serta antiplatelet. Tatalaksana hipertensi pada pasien dengan penyakit jantung dan pembuluh darah ditujukan pada pencegahan kematian, infark miokardial, stroke, pengurangan frekuensi dan durasi iskemia miokard dan memperbaiki tanda serta gejala. Target nilai tekanan darah yang di rekomendasikan oleh JNC VIII adalah target tekanan darah sistolik pada pasien berusia $>60$ tahun adalah $<150$ $\mathrm{mmHg}$ dan target tekanan darah pada pasien dewasa dengan diabetes atau penyakit ginjal kronik adalah $<140 / 90$ $\mathrm{mmHg}^{4}$. 
Jurnal Insan Farmasi Indonesia, 3(2) Desember 2020 (291-297)

Fef Rukminingsih

p-ISSN 2621-3184 ; e-ISSN 2621-4032

doi: 10.36387/jifi.v3i2.619

PJI merupakan penyakit yang menduduki 10 besar penyakit di Rumah Sakit St. Elisabeth Semarang. Pasien dengan Jaminan Kesehatan Nasional (JKN) mencapai angka 50\% dari total pasien yang mendapatkan pelayanan kesehatan di Instalasi Rawat Jalan. Berdasarkan uraian diatas perlu dilakukan penelitian untuk mengevaluasi ketercapaian target tekanan darah pada pasien PJI peserta JKN di Instalasi Rawat Jalan Rumah Sakit St. Elisabeth Semarang.

\section{METODE PENELITIAN}

Penelitian ini merupakan penelitian deskriptif observasional dengan menggunakan data retrospektif. Data diperoleh dari rekam medik pasien PJI. Kriteria inklusi penelitian ini adalah pasien peserta JKN dengan diagnosa PJI di Instalasi Rawat Jalan Rumah Sakit St. Elisabeth Semarang periode Oktober-Desember 2019 yang mendapat terapi antihipertensi, berumur 26-65 tahun, mempunyai data tekanan darah selama dua bulan berurutan, dengan atau tanpa penyakit penyerta. Data yang diambil meliputi nomor rekam medik, umur, jenis kelamin, penyakit penyerta, terapi hipertensi yang diperoleh, tekanan darah 2 bulan berurutan. Data yang diperoleh kemudian di analisis secara kualitatif dan kuantitatif. Analisis kualitatif dilakukan dengan mengelompokkan data berdasarkan karakteristik pasien. Analisis kuantitatif dilakukan dengan menghitung ketercapaian target tekanan darah pasien menurut guideline JNC 8.

\section{HASIL DAN PEMBAHASAN}

Berdasarkan hasil penelusuran data rekam medis pasien JKN dengan PJI periode Oktober - Desember 2019 diperoleh data sebanyak 88 pasien. Karakteristik pasien JKN dengan PJI di Rumah Sakit St. Elisabeth Semarang dapat dilihat pada Tabel 1.

Berdasarkan Tabel 1 diketahui jumlah pasien PJI meningkat dengan bertambahnya umur. Umur merupakan salah satu faktor risiko yang tidak dapat dikendalikan pada penyakit degeneratif. Risiko penyakit jantung cenderung meningkat hingga lebih dari 2,2 kali pada kelompok umur lebih dari 55 tahun ${ }^{5}$. 
Jurnal Insan Farmasi Indonesia, 3(2) Desember 2020 (291-297)

Fef Rukminingsih

p-ISSN 2621-3184 ; e-ISSN 2621-4032

doi: 10.36387/jifi.v3i2.619

Tabel 1. Karakteristik Pasien JKN dengan PJI di Rumah Sakit St. Elisabeth Semarang

\begin{tabular}{|c|c|c|}
\hline Karakteristik & Jumlah & $(\%)$ \\
\hline \multicolumn{3}{|l|}{ Umur (tahun) } \\
\hline $26-35$ & 3 & 3,41 \\
\hline $36-45$ & 9 & 10,23 \\
\hline $46-55$ & 30 & 34,09 \\
\hline $56-65$ & 46 & 52,27 \\
\hline \multicolumn{3}{|l|}{ Jenis Kelamin } \\
\hline Laki-laki & 64 & 72,73 \\
\hline Perempuan & 24 & 27,27 \\
\hline \multicolumn{3}{|c|}{ Jenis Penyakit Penyerta } \\
\hline DM tipe 2 & 27 & 30,68 \\
\hline $\mathrm{CHF}$ & 20 & 22,73 \\
\hline Hipertensi & 16 & 18,18 \\
\hline CKD & 7 & 7,95 \\
\hline Dislipidemia & 5 & 5,68 \\
\hline Atrial fibrilasi & 3 & 3,41 \\
\hline $\begin{array}{l}\text { Mitral } \\
\text { regurgitasi }\end{array}$ & 3 & 3,41 \\
\hline Asma & 2 & 2,27 \\
\hline GERD & 2 & 2,27 \\
\hline Lain-lain & 3 & 3,41 \\
\hline \multicolumn{3}{|c|}{ Jumlah Penyakit Penyerta } \\
\hline 0 & 31 & 35,22 \\
\hline 1 & 34 & 38,64 \\
\hline 2 & 16 & 18,18 \\
\hline 3 & 6 & 6,82 \\
\hline 4 & 1 & 1,14 \\
\hline
\end{tabular}

Jumlah pasien berjenis kelamin laki - laki lebih banyak yaitu sebanyak 64 pasien (72,73\%). Laki - laki cenderung mempunyai gaya hidup yang tidak sehat, kurang berolahraga dan merokok, sehingga memiliki tingkat insidensi kasus kardiovaskuler lebih tinggi dibandingkan perempuan. Merokok dapat menyebabkan

elastisitas pembuluh darah menurun sehingga dapat meningkatkan pengerasan pembuluh darah dan meningkatkan faktor pembekuan darah yang dapat memicu penyakit kardiovaskuler6 .

Jenis penyakit penyerta yang paling banyak adalah DM tipe 2 (30,68\%). DM tipe 2 dapat menyebabkan komplikasi mikrovaskuler dan makrovaskuler. Komplikasi makrovaskular termasuk penyakit jantung koroner, stroke, dan penyakit pembuluh darah perifer ${ }^{7}$. Penelitian klinik menunjukkan peningkatan risiko PJI sebanyak 4-8 kali pada penderita DM tipe $2^{8}$.

Sebanyak 57 pasien $(64,78 \%)$ mempunyai penyakit penyerta 1 sampai 4. Adanya penyakit penyerta dapat menambah kompleksitas pengobatan, menambah biaya pengobatan, dan berpengaruh pada motivasi untuk berobat. Semakin banyak penyakit penyerta akan mempengaruhi fungsi fisik tubuh ${ }^{9}$.

Berdasarkan Tabel 2 diketahui bahwa agen antihipertensi yang paling banyak digunakan pada penyakit jantung iskemik baik pada terapi 
Jurnal Insan Farmasi Indonesia, 3(2) Desember 2020 (291-297)

Fef Rukminingsih

p-ISSN 2621-3184 ; e-ISSN 2621-4032

doi: 10.36387/jifi.v3i2.619

tunggal maupun kombinasi adalah $\beta$ Blocker. $\beta$-Blocker yang digunakan adalah bisoprolol. $\beta$-Blocker direkomendasikan dalam pengobatan PJI karena mempunyai keuntungan sebagai anti hipertensi, anti iskemia, anti aritmia dan mampu mengurangi remodelling ventrikel ${ }^{10}$.

Tabel 2. Terapi Antihipertensi pada Pasien JKN dengan PJI di Rumah Sakit St Elisabeth Semarang.

\begin{tabular}{|c|c|c|}
\hline Terapi Antihipertensi & $\mathrm{Jml}$ & $\%$ \\
\hline \multicolumn{3}{|l|}{ Tunggal } \\
\hline$\beta$-Blocker & 34 & 38,6 \\
\hline ARB & 7 & 705 \\
\hline & & $-c$ \\
\hline & & 5,00 \\
\hline $\mathrm{CCB}$ & 2 & 2,27 \\
\hline \multicolumn{3}{|l|}{ Kombinasi } \\
\hline $2 \beta$-Blocker + ARB & 22 & 25 \\
\hline$\beta$-Blocker + ACEI & 10 & $\begin{array}{c}11,3 \\
6\end{array}$ \\
\hline$\beta$-Blocker $+\mathrm{CCB}$ & 5 & 5,68 \\
\hline $\mathrm{CCB}+\mathrm{ARB}$ & 1 & 1,14 \\
\hline $\begin{array}{l}3 \text {-Blocker }+\mathrm{ARB}+ \\
\mathrm{CCB}\end{array}$ & 1 & 1,14 \\
\hline $\begin{array}{l}\beta \text {-Blocker }+ \text { ACEI } \\
+\mathrm{ARB}\end{array}$ & 1 & 1,14 \\
\hline
\end{tabular}

Sebanyak 48 pasien mendapat agen antihipertensi tunggal, 38 pasien mendapat 2 agen dan hanya 2 pasien yang mendapat 3 agen. Semakin sederhana pola pengobatan akan meningkatkan kepatuhan pasien dalam menggunakan obat sehingga akan berdampak pada keberhasilan terapi ${ }^{11}$. Tabel 3. Ketercapaian target tekanan darah pasien PJI di RS St. Elisabeth Semarang

\begin{tabular}{llcr}
\hline No & $\begin{array}{c}\text { Target } \\
\text { Tekanan } \\
\text { Darah }\end{array}$ & Jumlah & $\%$ \\
\hline 1. & Tercapai & 82 & 93,1 \\
& & & 8 \\
2. & $\begin{array}{l}\text { Tidak } \\
\text { tercapai }\end{array}$ & 6 & 6,82 \\
\hline
\end{tabular}

Berdasarkan Tabel 3 diketahui sebanyak 82 pasien $(93,18 \%)$ mencapai target tekanan darah sesuai dengan guideline JNC 8. Ketercapaian target tekanan darah pasien PJI ini lebih besar dibandingkan ketercapaian target tekanan darah pasien rawat inap dengan gagal jantung kongestif di rumah yang sama yaitu $81,67 \%{ }^{12}$.

Salah satu faktor yang berpengaruh pada keberhasilan terapi adalah pola pengobatan atau kompleksitas regimen ${ }^{11}$. Dalam penelitian ini diketahui bahwa 86 pasien mendapat agen antihipertensi sebanyak 1-2 obat. Hal ini diduga turut berpengaruh dalam pencapaian target tekanan darah pasien. Semakin sedikit jumlah obat yang dikonsumsi dan semakin kecil frekuensi minum obat 
Jurnal Insan Farmasi Indonesia, 3(2) Desember 2020 (291-297)

Fef Rukminingsih

p-ISSN 2621-3184 ; e-ISSN 2621-4032

doi: 10.36387/jifi.v3i2.619

maka kepatuhan pasien akan meningkat ${ }^{13}$. Semakin besar keberhasilan mencapai target terapi maka risiko kematian akibat PJI akan menurun.

\section{KESIMPULAN}

Ketercapaian target tekanan darah berdasarkan JNC 8 dari 88 pasien PJI di Instalasi Rawat Jalan RS St. Elisabeth Semarang adalah sebesar $93,18 \%$.

\section{UCAPAN TERIMA KASIH}

1. Direktur RS St. Elisabeth Semarang.

2. Direktur Politeknik Katolik Mangunwijaya Semarang

\section{DAFTAR PUSTAKA}

1. Kemenkes RI, 2018, Hasil Utama Riskesdas 2018, Badan Penelitian dan Pengembangan Kesehatan Jakarta.

2. Sukandar EY, Andrajati R, Sigit JI, dkk, 2013, ISO Farmakoterapi, PT. ISFI Penerbitan, Jakarta, 134-174.

3. Marliani L, 2013, Hipertensi, PT Gramedia, Jakarta.

4. James PA, Oparil S, Carter BL, $\mathrm{dkk}, 2014$, Evidence-Based Guidline for the Management of High Blood Pressure in Adults: (JNC8), Jama, 311, (5), 507-20.

5. Delima, Mihardja L, Siswoyo

H, 2009, Prevalensi dan Faktor determinan penyakit jantung di Indonesia, Buletin Peneliti Kesehatan, 37 (3), 142-159.

6. Aisyiyah FN, 2009, Faktor Risiko Hipertensi pada Empat Kabupaten / Kota dengan Prevalensi Hipertensi Tertinggi di Jawa dan Sumatera, Institut Pertanian Bogor.

7. Triplitt CL, Repas T, Alvarez C, 2015, Diabetes Melitus dalam Pharmacotherapy Handbook, 9ed, McGraw-Hill Education, United State, 161175.

8. Darmojo B, 2006, Data epidemiologi penyakit jantung dan pembuluh darah Dalam Penyakit jantung iskemik, Sari Pustaka Kardiovaskuler, Badan Penerbit UNDIP, Semarang, 1-12.

9. Sathvik BS, Parthasarathi G, Narahari, MG, dkk, 2008, An assessment of the quality of life in hemodialysis patients using the WHOQOL - BRF questionnaire, Indian Journal of Nephrology, 18 (4), 141149.

10. Perki, 2015, Pedoman Tatalaksana Hipertensi Pada Penyakit Kardiovaskuler, Jakarta, 1-16.

11. Saragi S, 2011, Panduan Penggunaan Obat, Rosemata Publisher, Jakarta, 1-36.

12. Rukminingsih F, dan Susanto TC, 2020, Pengukuran Tekanan Darah Pada Pasien 
Jurnal Insan Farmasi Indonesia, 3(2) Desember 2020 (291-297)

Fef Rukminingsih

p-ISSN 2621-3184; ; e-ISSN 2621-4032

doi: 10.36387/jifi.v3i2.619

Gagal Jantung Kongestif di Instalasi Rawat Inap Rumah Sakit St. Elisabeth Semarang, Jurnal Riset Kefarmasian Indonesia, 2 (1), 10-16.

13. Rosyida L, Priyandani Y, Sulistyarini A, dkk, 2015, Kepatuhan Pasien Pada Penggunaan Obat Antidiabetes Dengan Metode Pill Count dan MMAS-8 di Puskesmas Kedurus Surabaya. Jurnal Farmasi, 2 (2), 39-44. 